\title{
Library and Information Science Research 2002: A Bibliography of Master's Papers from the University of North Carolina School of Information and Library Science
}

The following master's papers were submitted in partial fulfillment of the requirements for the master of science in information and library science degree at the School of Information and Library Science at the University of North Carolina at Chapel Hill. The subject headings used to index them have been given. The numbers added to the citations will facilitate identification of master's papers requested on interlibrary loan.

Ballenger, Martha. "Relationship Between Learning Style and User Satisfaction with a Web Based Health Information System." 29 pages. Nov.2002. No. 2788.

Headings: Cognitive Style; Usability Testing; User Satisfaction; Health Information System; World Wide Web.

Brockway, Kenneth Andrew. "Database Support for Microchip Identification in Companion Animal Identification." 58 pages. July 2002. No. 2789.

Headings: Animal welfare-Databases; Database design; Identification numbers, Personal-United States; Integrated circuits; Pet supplies.

Case, Christy. "The State of Lesbian Detective Fiction in Four Public Libraries in North Carolina. 41 pages. July 2002. No. 2790.

Headings: Libraries-North Carolina; Online catalogs; Subject headings_-Special subjects-Fiction.

Cash, Audrey. "HIV/AIDS Information on Government Health Websites in Developing Countries." 39 pages. Nov.2002. No. 2791.

Headings: AIDS (Disease)—Developing countries; Developing countries; HIV (Viruses)— Developing countries; Information technology—Developing countries; Web sitesEvaluation.

Gundlach, Kathryn R. "Patterns of Genre Fiction Readers: A Survey of Durham County Library Patrons." 37 pages. Nov. 2002. No. 2792.

Headings: Public libraries; Fiction; Reader guidance; Reading interests.

Hanrath, R. Scott. "A Usability Study of a Tool for Contributor-Supplied Metadata Creation: The Use of Metadata Element Definitions and Examples in Online Help." 30 pages. Nov. 2002. No. 2793.

Headings: Metadata; Author-generated metadata; Usability.

Holmgren, Stephanie. "Following Quality Guidelines: An Assessment of Library Web sites Offering Consumer Health Information." 98 pages. Nov. 2002. No. 2794.

Headings: Consumer education; Health—Information services; Web sites-Design; Web sites-Evaluation. 
Johnson, Kate. "The Design of Secure Mobile Databases: An Evaluation of Alternative Secure Access Models." 110 pages. Aug. 2002. No. 2795.

Headings: Database management; Database design; Database security.

Kern, Matthew. "Digital Neighborhoods: An Analysis of Local History Materials in the Digital World." 63 pages. Nov. 2002. No. 2796.

Headings: Electronic data archives-Conservation and restoration; Information systems—Special subjects_Local history and records; Internet-Public Libraries; Preservation of library materials-Automation.

Kilfoil, Jessica. "Projecting the Map Collection: Academic Map Libraries and Communicating the Value of Services on the World Wide Web." 55 pages. Nov. 2002. No. 2797.

Headings: Library Websites; Map collections_Public relations; Academic librariesPublic relations; Libraries-Special collections-Maps.

Langley, Ashley Richardson. "The Differences Between Users' Queries Using Different Search Engine Interfaces." 30 pages. Nov. 2002. No. 2798.

Headings: Online searching; User information-seeking behavior; Internet search engines.

Lee, Chris. "Obstacles in Web-Based Information and Referral." 35 pages. Nov. 2002. No. 2799.

Headings: Community information services; Information networks; Information services; Referral; Web usability.

Lerette, Bridget T. "Archival Materials Exhibited in an Art Museum: A Case Study of Museum-Library Collaboration." 42 pages. Aug. 2002. No. 2800.

Headings: Museum-library relations-Case studies; Manuscripts-Exhibits and displays; Rhode Island School of Design. Museum of Art; Providence Public Library; Yamamoto, Lynne, 1961- .

Lovett, Susan S. "Do You See Your Family?: An Examination of Racially Mixed Characters \& Families in Children's Picture Books Available in School Media Centers." 37 pages. Nov. 2002. No. 2801.

Headings; Racially mixed individuals-Children's literature; School libraries-North Carolina; School library-Collections; Minorities in literature; Picture books for children.

Merrill, Cynthia. "The Impact of Patient Internet Information on the Doctor-Patient Relationship." 42 pages. Aug. 2002. No. 2802.

Headings: Physician-patient relations; Attitudes toward computers; Medical information; Patient education; Internet searching.

Morgan, Kevin J. "An Online System for Evaluation of Classroom Instruction: Design and Implementation." 39 pages. Nov. 2002. No. 2803.

Headings: Student surveys-Test format-Student evaluation of teacher performance; Student attitudes; Design/information systems.

Nasser, Kathryn M. "Information Exchange and Intellectual Climate: Adoption of an Online Events Calendar at a University." 62 pages. Nov. 2002. No. 2804.

Headings: Colleges and universities; Events calendar; Groupware; Technology adoption.

Osterman, Anne Charlotte. “Collections Supporting Women's Studies Majors in the United States." 48 pages. Nov. 2002. No. 2805.

Headings: Women's Studies; Collection development; College and university libraries.

Parmelee, Mary. "Design for Change: Ontology-Driven Knowledgebase Applications for Dynamic Biological Domains." 105 pages. Nov. 2002. No. 2806.

Headings: Application software-Development; Information storage and retrievalDesign; Information systems-Design; Knowledge representation; Ontology. 
Porter, Dorothy Carr. "Medievalists' Use of Electronic Resources: The Results of a National Survey of Faculty Members in Medieval Studies." 72 pages. Nov. 2002. No. 2807.

Headings: Medievalists-United States; Scholarly electronic publishing; Academic Web sites; Humanities-Electronic information services.

Priest, Ruffin. "Attitudes of School Librarians Toward the Inclusion of Graphic Novels in School Library Collections." 42 pages. Nov. 2002. No. 2808.

Headings: Graphic novels; Comic books; K-12 libraries; Collection development.

Rhodes, Rebecca. "Libraries, Librarianship and Library Education in the Czech Republic." 81 pages. Nov. 2002. No. 2809.

Headings: Interview—Czech Republic; Interview—Library education; Librarianship— Czech Republic; Libraries-Czech Republic; Library education-Czech Republic.

Robbins, Elizabeth E. "Evaluation of Participation in an Online Community of Practice." 95 pages. Nov. 2002. No. 2810.

Headings: Community—Communities of Practice; Community—Participation; Internet-Online communities; Information systems-Content management system; Internet-Discussion group.

Schmidt, Krista. "Science and Engineering-Based Federal Library Web Sites and Public Accessibility of Information and Resources." 40 pages. Nov. 2002. No. 2811.

Headings: Government information-Public access; Government libraries; Government publications-Distribution and acquisition; Information systems-Special subjects-Governments; Internet—Scientific and technical libraries; Web sitesEvaluation.

Sharek, Zachariah. "The Effects of Stemming, Stopwords and Multi-word Phrases on Zipfian Distributions of Text." 65 pages. Nov. 2002. No. 2812.

Headings: Information retrieval; Information retrieval-Zipf's law.

Singh, Gayatri. "Evolving Space: An Examination of Coffee Shops in Academic Libraries." 30 pages. Nov. 2002. No. 2813.

Headings: Library cafes; Academic libraries-Policy statements; College and university libraries-Coffee; College and university libraries_Food; College and university libraries-Beverages.

Thomas, William Joseph. "Cherokee Printing, Cherokee Identity." 81 pages. Nov. 2002. No. 2814.

Headings: Cherokee language-Writing-Social aspects; Cherokee IndiansNewspapers; Cherokee Phoenix (New Echota, Ga.); Cherokee Indians-History; Indians of North America-Georgia-Newspapers.

Valetich, Carla S. "The Response of Socially Aware Librarians to National Crisis: A Case Study of Selected Electronic Mail from the Social Responsibilities Round Table, September 2001-July 2002." 77 pages. Aug. 2002. No. 2815.

Headings: World Trade Center terrorist attack, 2001; Librarianship—Social aspects; American Library Association. Social Responsibilities Round Table.

Ward, Jewel. "A Quantitative Analysis of Dublin Core Metadata Element Set (DCMES) Usage in Data Providers Registered with the Open Archives Initiative (OAI)." 68 pages. Nov. 2002. No. 2816.

Headings: Electronic data archives-Standards; Virtual library; Metadata; Dublin Core; Preprints; Science and technology_Databases.

Zhao, Yuming. "What is the Decision-Making Process of Computer Service Technicians in Their Routine Work?" 52 pages. Aug. 2002. No. 2817.

Headings: Decision making; Problem solving; Computer service. 